\title{
Dossiê História e Identidades no Medievo
}

\author{
Monah Nascimento Pereira
}

A Revista Vernáculo tem a satisfação de apresentar o Dossiê História e Identidades no Medievo. Os artigos aqui compilados foram produzidos no âmbito do programa de pós graduação em História da Universidade Federal do Paraná, a partir do debate proposto aos discentes da linha de pesquisa Cultura e Poder. A temática em questão é bastante atual, uma vez que a busca por compreender a formação de identidades socioculturais tem movido a pesquisa de diversos historiadores, dentro dos mais variados recortes espaço-temporais. Para tentarmos entender quem eram os sujeitos históricos sobre os quais pesquisamos, é necessário analisar como estes se identificavam e, muitas vezes, isso está intimamente ligado com a definição do eu e do outro. Tais identidades são, portanto, subjetivas e mutáveis, sempre ligadas às diferentes formas de sentir e pensar em cada contexto histórico.

Com relação ao medievo ocidental, como recorte específico, não poderia ser diferente. Realizar este tipo de reflexão é fundamental, especialmente se levarmos em consideração a alteridade de tal contexto, se comparado ao nosso próprio. Assim, os textos presentes no dossiê buscam analisar tais criações identitárias, levando em consideração os atores sociais que participaram na criação desses ideais, bem como a normatização social e cultural presente nos mesmos. 
Em seu "Trovadores e jograis: mester de identidade sociocultural", Ana Luiza Mendes busca apontar que jograis e trovadores eram agentes socioculturais importantes nas cortes ibéricas baixo medievais, de modo a transmitirem, através de seu ofício, valores culturais e sociais. A autora também busca ressaltar a forma como a produção trovadoresca e seus porta vozes estavam entremeados no jogo do poder, por sua própria constituição, uma vez que atingiam pessoas em diferentes níveis sociais, carregando consigo mensagens com as mais diversas intenções.

Mateus Sokolowski também tem como foco a baixa idade média ibérica, mais especificamente o reinado de Afonso X e as cantigas de Santa Maria, produzidas durante seu governo. O texto procura ressaltar que as cantigas não retratavam o mundo tal como ele era, mas sim como ele se queria fazer ver por seus produtores. Assim, "revelam modelos e símbolos importantes para compreensão do exercício do poder no contexto histórico do reinado de Afonso X".

Da mesma maneira, Leonardo Girardi debruça-se sobre o tratado "Espelho de Reis", de Álvaro Pelayo. Girardi busca estender sua análise do texto do frei galego para além de questões puramente políticas, observando como o debate acerca da teocracia pontifícia e da centralização política se concatena com uma construção identitária pautada em intenções políticas. História e cultura surgem como grandes eixos a partir do qual se analisa toda a teorização política, que busca orientar um determinado grupo de indivíduos de acordo com um parâmetro construído de uma sociedade idealizada.

Por fim, Monah Pereira, em seu "Identidade e tradição: História e wyrd na versão anglo-saxônica da De Consolatione Philosophiae (séculos IX- 
X)" procura "compreender o modo como as noções de história e destino presentes no texto contribuem para a criação de um ideal de identidade calcado na religião e na tradição latino cristã". A autora analisa o período alfrediano da Inglaterra anglo-saxônica, no qual houve uma prolífica difusão de traduções vernáculas de obras da patrística cristã. Seu texto explora a versão anglo-saxônica da De Consolatione Philosophiae e a forma como esta trabalha com os conceitos de história e destino. Estes são instrumentais na construção de uma nova visão acerca do poder e da identidade de um grupo em um contexto de significativas transformações socioculturais.

Esperamos que este dossiê possa contribuir para a discussão relativa à questão das identidades dentro do campo da história, apontando como tal tema pode ser utilizado para debater não apenas questões culturais, mas também um viés mais subjetivo e multifacetado da tradicional história política. Boa leitura! 